\title{
Nitrate removal in a restored riparian groundwater system: functioning and importance of individual riparian zones
}

\author{
S. Peter ${ }^{1,2}$, R. Rechsteiner ${ }^{1,2}$, M. F. Lehmann ${ }^{3}$, R. Brankatschk ${ }^{1}$, T. Vogt $^{1,4}$, S. Diem ${ }^{4}$, B. Wehrli ${ }^{1,2}$, K. Tockner ${ }^{5}$ and $^{\text {. }}$ \\ E. Durisch-Kaiser ${ }^{1,2}$ \\ ${ }^{1}$ Institute of Biogeochemistry and Pollutant Dynamics, ETH Zurich, 8092 Zurich, Switzerland \\ ${ }^{2}$ Eawag, Swiss Federal Institute of Aquatic Science and Technology, 6047 Kastanienbaum, Switzerland \\ ${ }^{3}$ Institute for Environmental Geosciences, University of Basel, 4056 Basel, Switzerland \\ ${ }^{4}$ Eawag, Swiss Federal Institute of Aquatic Science and Technology, 8600 Dübendorf, Switzerland \\ ${ }^{5}$ IGB, Leibniz-Institute of Freshwater Ecology and Inland Fisheries, 12587 Berlin, Germany
}

Correspondence to: S. Peter (speter@env.ethz.ch)

Received: 20 April 2012 - Published in Biogeosciences Discuss.: 11 June 2012

Revised: 28 September 2012 - Accepted: 2 October 2012 - Published: 6 November 2012

\begin{abstract}
For the design and the assessment of river restoration projects, it is important to know to what extent the elimination of reactive nitrogen $(\mathrm{N})$ can be improved in the riparian groundwater. We investigated the effectiveness of different riparian zones, characterized by a riparian vegetation succession, for nitrate $\left(\mathrm{NO}_{3}^{-}\right)$removal from infiltrating river water in a restored and a still channelized section of the river Thur, Switzerland. Functional genes of denitrification (nirS and nosZ) were relatively abundant in groundwater from willow bush and mixed forest dominated zones, where oxygen concentrations remained low compared to the main channel and other riparian zones. After flood events, a substantial decline in $\mathrm{NO}_{3}^{-}$concentration $(>50 \%)$ was observed in the willow bush zone but not in the other riparian zones closer to the river. In addition, the characteristic enrichment of ${ }^{15} \mathrm{~N}$ and ${ }^{18} \mathrm{O}$ in the residual $\mathrm{NO}_{3}^{-}$pool (by up to $22 \%$ for $\delta^{15} \mathrm{~N}$ and up to $12 \%$ for $\delta^{18} \mathrm{O}$ ) provides qualitative evidence that the willow bush and forest zones were sites of active denitrification and, to a lesser extent, $\mathrm{NO}_{3}^{-}$removal by plant uptake. Particularly in the willow bush zone during a period of water table elevation after a flooding event, substantial input of organic carbon into the groundwater occurred, thereby fostering postflood denitrification activity that reduced $\mathrm{NO}_{3}^{-}$concentration with a rate of $\sim 21 \mu \mathrm{molN} \mathrm{N}^{-1} \mathrm{~d}^{-1}$. Nitrogen removal in the forest zone was not sensitive to flood pulses, and overall $\mathrm{NO}_{3}^{-}$removal rates were lower $\left(\sim 6 \mu \mathrm{moll}^{-1} \mathrm{~d}^{-1}\right)$. Hence, discharge-modulated vegetation-soil-groundwater coupling
\end{abstract}

was found to be a key driver for riparian $\mathrm{NO}_{3}^{-}$removal. We estimated that, despite higher rates in the fairly constrained willow bush hot spot, total $\mathrm{NO}_{3}^{-}$removal from the groundwater is lower than in the extended forest area. Overall, the aquifer in the restored section was more effective and removed $\sim 20 \%$ more $\mathrm{NO}_{3}^{-}$than the channelized section.

\section{Introduction}

Fixed nitrogen $(\mathrm{N})$ input into aquatic systems has tremendously increased over the past several decades (Seitzinger et al., 2006), and one third of the anthropogenic $\mathrm{NO}_{3}^{-}$and ammonium is stored in groundwater, soils, and vegetation (Gruber and Galloway, 2008). High N loading can cause eutrophication of rivers, lakes, and coastal zones, and a deterioration of drinking water quality (Powlson et al., 2008). River ecosystems can play an important role in the processing of nutrients (Fischer et al., 2002), in particular through the natural removal of excess $\mathrm{NO}_{3}^{-}$by denitrification and other uptake and transformation processes in riparian buffer zones (Mayer et al., 2007; Verhoeven et al., 2006). However, over the past two centuries, river regulation and the removal of wetlands have diminished the ecological and biogeochemical functionality of river systems in many parts of the world (Tockner and Stanford, 2002).

The ecological functioning (e.g. the capacity to remove $\mathrm{NO}_{3}^{-}$) of a riparian system strongly depends on the quality 
and connectivity of different functional process zones (FPZs, sensu Thorp et al., 2006), which are patches that differ from their surroundings in structure and function, and are functionally connected via surface and subsurface flow paths (Fisher and Weiter, 2005). Hydrologic connectivity includes vertical (river-groundwater), lateral (river-landscape) and longitudinal exchange processes (Boulton, 2007), and can affect $\mathrm{NO}_{3}^{-}$elimination along subsurface flow paths (Baker and Vervier, 2004; Burt and Pinay, 2005). Hinkle et al. (2001), for example, demonstrated that denitrification depends on subsurface travel times and the rate of water exchange between the river and its hyporheic zone.

Subsurface flow paths link different zones that carry different reactants, and thus modulate the distribution of biogeochemically relevant substrates, possibly enhancing microbial reaction rates (Edwards, 1998). Heterotrophic microbial metabolism in hyporheic zones is directly limited by the availability of organic carbon (OC) (Baker et al., 1999; Findlay and Sinsabaugh, 2003; Sobczak and Findlay, 2002). Also, denitrification in $\mathrm{NO}_{3}^{-}$-rich groundwater is primarily controlled by the redox conditions and the availability of electron donors (i.e. bioavailable OC) (Rivett et al., 2008). Organic carbon can enter the subsurface from deep-rooted vegetation, buried $\mathrm{C}$-lenses, and through episodic leaching of the overlying riparian soils (Clinton et al., 2002; Gift et al., 2010; Schade et al., 2001), leading to zones with high biogeochemical activity, often referred to as biogeochemical hot spots (McClain et al., 2003). Flood events mediate the coupling of the soil and root horizon with the groundwater leading to introduction of labile OC (Peter et al., 2012) and increased $\mathrm{NO}_{3}^{-}$uptake by plants (Clement et al., 2003; Hefting et al., 2004).

In this study we hypothesize that riparian zones differing in their vegetation cover will differently affect $\mathrm{NO}_{3}^{-}$removal from riparian groundwater. Furthermore, the $\mathrm{NO}_{3}^{-}$removal processes are expected to be modulated by hydrological connectivity, which can represent an important constraint on substrate availability $\left(\mathrm{OC}, \mathrm{NO}_{3}^{-}\right)$. To test these assumptions, we investigated the main sources of $\mathrm{N}$ to the groundwater and estimated $\mathrm{N}$ budgets for different riparian zones along a crosssection of a recently restored and a still channelized section of the river Thur, Switzerland. Furthermore, we studied the potential links between water table fluctuations and OC-controlled $\mathrm{NO}_{3}^{-}$removal in the groundwater. Our main objectives are (i) to investigate which riparian zones are particularly conducive to $\mathrm{NO}_{3}^{-}$removal, (ii) to identify the relevant processes for $\mathrm{NO}_{3}^{-}$removal, (iii) to assess the contribution and relevance of the individual zones to whole system $\mathrm{NO}_{3}^{-}$removal, and (iv) to understand the role of vegetation and flood events for $\mathrm{NO}_{3}^{-}$removal on the scale of the whole aquifer. Seasonal sampling campaigns were conducted using a series of 13 piezometers placed in different zones of the restored and the channelized sections, corresponding to a river-riparian succession gradient. We collected data on nu- trient and $\mathrm{OC}$ concentrations, the dual stable isotope ratios of $\mathrm{NO}_{3}^{-}\left(\delta^{15} \mathrm{~N}, \delta^{18} \mathrm{O}\right)$, and the abundance of functional genes encoding different steps in denitrification. The observations allowed assessing the functionality of a restored river corridor for nitrogen elimination.

\section{Materials and methods}

\subsection{Study site}

The river Thur originates in the limestone formation of the Mount Säntis region (2500 m a.s.l), drains a catchment area of $1700 \mathrm{~km}^{2}$ on the NE Swiss Plateau, and enters the river Rhine at $345 \mathrm{~m}$ a.s.l. The river Thur exhibits the dynamic flow regime of an Alpine river because reservoirs and natural lakes are absent in the catchment. Maximum, mean, and minimum flow rates are 1130,50 , and $2.24 \mathrm{~m}^{3} \mathrm{~s}^{-1}$, respectively, for the time series of 1904 to 2000 (Binderheim-Bankay et al., 2000). It was channelized in the 1890 s to prevent flooding of the river valley. In the 1970s, a plan to concurrently improve the flood protection and ameliorate the ecological state of the river corridor was elaborated. Since the early 1990s, several $1-3 \mathrm{~km}$ long river sections were widened to allow for the formation of alternating gravel bars and to increase hydrological connectivity between the main channel and its riparian zone. Riparian succession processes were stimulated and, as a consequence, habitat diversity increased (Pasquale et al., 2011).

The study sites, instrumented for an interdisciplinary research project on river restoration (Schneider et al., 2011), were located at Niederneunforn (Canton Thurgau, Switzerland) in a $2 \mathrm{~km}$ long restored river corridor and $1 \mathrm{~km}$ upstream in a channelized section. (Fig. 1a). In the restored river sections, we identified four distinct zones across a riverriparian succession gradient (Fig. 1a): (1) a bare gravel bank (gravel); (2) exposed gravel, colonized by the tall pioneer grass Phalaris arundinacea (grass); (3) a second flooding terrace dominated by Salix viminalis (willow bush); and (4) the alluvial mixed ash forest (forest) located 50-60 m away from the edge of the main channel. At the non-restored site, no riparian succession was established and pasture made up the only FPZ. The main channel represents the main source of the infiltrating water (Vogt et al., 2010). The piezometers penetrated the aquifer down to $8 \mathrm{~m}$ depth ( 3 to $7 \mathrm{~m}$ screened), allowing water sample collection from the saturated zone. The saturated zone consists of a deep sandy gravel layer (5$6 \mathrm{~m}$ ), sealed by an impermeable clay layer at the bottom and covered by a poorly permeable sand and loam layer at the top. In general, the study site is characterized by a good hydraulic and hydrological connectivity between river water and riparian groundwater (Vogt et al., 2010). The riparian groundwater is primarily fed by the infiltrating river water and the contribution of vertical water flow from the unsaturated zone is negligible (Vogt et al., 2012; Diem et al., 


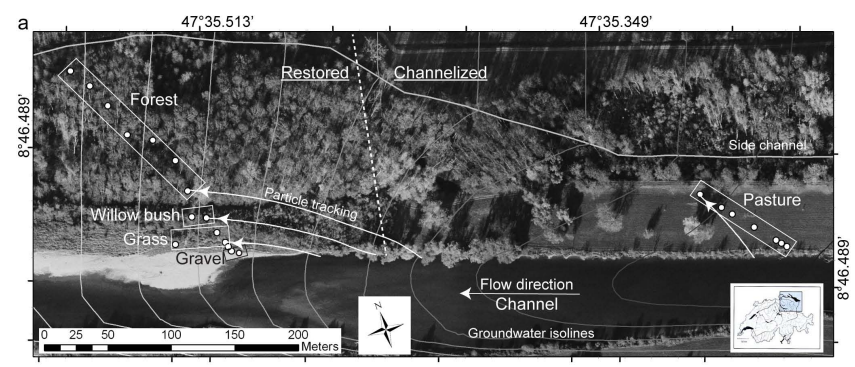

b

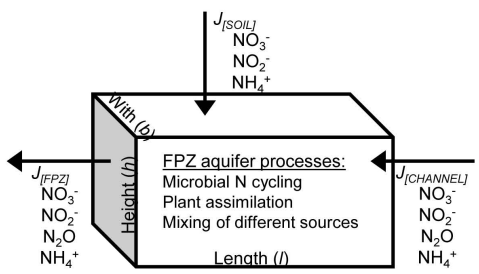

Fig. 1. (a) Field site at Niederneunforn, Switzerland, with the installed piezometers in the restored and channelized section of the river Thur and the different FPZs indicated. The modeled groundwater flow field (Diem et al., 2012) is illustrated by isopotential lines (equidistance of $10 \mathrm{~cm}$ ) and by selected flow paths. To ease a comparison with previous studies, e.g. Vogt et al. (2010) and Schneider et al. (2011), the link to the original piezometer names is given here for the individual FPZs, beginning with the piezometer closest to the main channel: gravel: R050 and R060; grass: R042, R051, and R052; willow bush: R041 and R058; forest: R017, R023, R024, R019, R025, R026, and R021; and pasture: R001, R004, R005, R009, R011, R012, and R014. (b) Schematic illustration of the $\mathrm{N}$ groundwater budget. River channel and the soil are the two main sources for the groundwater $\mathrm{N}$ pool, and the individual FPZs are directly connected to the channel.

2012). Accordingly, the groundwater below the gravel bar and the grass zone is mainly comprised of freshly infiltrated river water $(\sim 23 \mathrm{~h}$ travel time), while subsurface travel times from the river to the willow bush zone are $\sim 4.5$ days, and to the forest on the order of weeks (Vogt et al., 2010). In the channelized section, the hydrological connectivity is reduced, that is, $\sim 3$ days travel time for the river water to the first and 11 days to the last piezometer in the transect. Small scale processes along the soil-groundwater interface in the first meters of infiltration were documented in detail by Vogt et al. (2012).

\subsection{Hydrodynamics}

Sensors with an integrated data logger for continuous measurements (15 min interval) of hydraulic head and electrical conductivity (DL/N 70, STS AG, Switzerland; error of single measurement is $\pm 0.1 \%$ for head and $\pm 2 \%$ for electrical conductivity) were installed in the river channel and in the piezometer of the willow bush zone. The time series of hydraulic head and electrical conductivity were recorded from June 2008 to July 2009. A three-dimensional steady-state groundwater flow model (Feflow, DHI-WASY GmbH) was setup to derive the groundwater flow paths and Darcy fluxes for the different FPZs under base flow conditions. Details of the model setup, the boundary conditions and the model calibration are described in Diem et al. (2012). In short, the modeling domain has an extension of $1200 \mathrm{~m} \times 400 \mathrm{~m}$, with the longer axis parallel to the river Thur. The model is restricted to the gravel-and-sand aquifer with a thickness of $5-6 \mathrm{~m}$. The river was included as a third-type boundary condition with water levels at a discharge of $23 \mathrm{~m}^{3} \mathrm{~s}^{-1}$, which were adopted from an existing hydraulic model (Pasquale et al., 2011). In the side channels (Fig. 1a), continuously measured data at water level gauges were integrated with data from periodic measurements at fixed points. The hydraulic conductivity field was calibrated using travel time information derived by time series analysis of electrical conductivity data (Vogt et al., 2010). The riverbed transfer rates (conductance) were automatically calibrated to measured groundwater levels in selected piezometers. The flow paths and the average Darcy flux along the flow paths were extracted from particle backtracking results (Diem et al., 2012).

\subsection{Sampling}

Between April 2008 and June 2009, groundwater was sampled three times during flood events, once 7 days after a peak flow event, and four times during base to average flow conditions of the river Thur (Table 1, Fig. 2a). At each date, surface river water was sampled and a $12 \mathrm{~V}$ purge pump was used to collect water at the piezometers. Prior to collecting groundwater samples, the electric conductivity and temperature were monitored (WTW, Nova Analytics) until constant values were reached. Samples for $\mathrm{O}_{2}$ analysis were filled bubble free into volumetric glass flasks and immediately fixed for Winkler analysis (Grasshoff et al., 1999). Samples for measuring concentrations of nitrous oxide $\left(\mathrm{N}_{2} \mathrm{O}\right)$ were taken on 15 April and 23 June 2009 only. Water was filled bubble free in serum flasks, amended with $\mathrm{CuCl}_{2}$, and sealed gas tight. Samples for measuring total organic carbon (TOC), total N (TN), and dissolved OC (DOC) concentrations were transferred into muffled $\left(450^{\circ} \mathrm{C}\right)$ glass tubes. TOC and TN samples were acidified with $2 \mathrm{~mol}^{-1} \mathrm{HCl}(\mathrm{pH}$ 3). All samples were stored at $4{ }^{\circ} \mathrm{C}$ in the dark for later analysis. Samples for DOC analysis were immediately filtered through pre-combusted $\left(220^{\circ} \mathrm{C}, 4 \mathrm{~h}\right)$ glass fiber filters (GF/F, Whatman), stored in muffled glass bottles, and analyzed within 24 hours after sample collection. To analyze the suspended bacterial gene abundance, $60-1200 \mathrm{ml}$ water was filtered through $0.22 \mu \mathrm{m}$ polycarbonate filters (Millipore), and filters were stored in sterilized plastic tubes at $-20^{\circ} \mathrm{C}$ until further analysis.

\subsection{Chemical analyses}

TOC and DOC concentrations were measured on unfiltered and filtered water samples, respectively, on a Shimadzu TOC 
Table 1. Temperature, mean discharge, flow regime of the river Thur, and the number $(n)$ of samples taken or piezometers sampled in each riparian zone during the sampling campaigns.

\begin{tabular}{|c|c|c|c|c|c|c|c|c|c|}
\hline Sampling date & $\begin{array}{l}\text { Water temp. } \\
\left({ }^{\circ} \mathrm{C}\right)\end{array}$ & $\begin{array}{l}\text { Discharge } \\
\left(\mathrm{m}^{3} \mathrm{~s}^{-1}\right)\end{array}$ & Flow regime & $\begin{array}{l}\text { Channel } \\
(n)\end{array}$ & $\begin{array}{l}\text { Gravel } \\
(n)\end{array}$ & $\begin{array}{l}\text { Grass } \\
(n)\end{array}$ & $\begin{array}{l}\text { Willow bush } \\
(n)\end{array}$ & $\begin{array}{l}\text { Forest } \\
(n)\end{array}$ & $\begin{array}{l}\text { Pasture } \\
(n)\end{array}$ \\
\hline 23 April 2008 & 8.0 & 347 & high & 4 & flooded & flooded & 1 & 7 & 7 \\
\hline 17 June 2008 & 14.4 & 35.6 & average & 4 & 0 & 1 & 1 & 5 & 5 \\
\hline 15 July $2008^{3}$ & 16.8 & 242 & high & 3 & flooded & 1 & 1 & 5 & 4 \\
\hline 2 Sept 2008 & 17.8 & 16.5 & base & 1 & 2 & 2 & 1 & 4 & 0 \\
\hline 6 January $2009^{3}$ & 0.5 & 14.2 & base & 1 & 1 & 2 & 1 & 4 & 0 \\
\hline 15 April $2009^{1,2}$ & 9.6 & 62.8 & average & 2 & 2 & 3 & 2 & 4 & 4 \\
\hline 17 June 2009 & 15.1 & 100 & high* & 1 & 1 & 2 & 1 & 3 & 0 \\
\hline 23 June $2009^{1,2}$ & 11.5 & 201 & high** & 1 & flooded & 2 & 2 & 4 & 0 \\
\hline
\end{tabular}

* Onset of a flood; ** declining flood after one week of highly variable discharge conditions.

${ }^{1}$ Analyzed for $\mathrm{N}_{2} \mathrm{O}$ concentration; ${ }^{2}$ analyzed for functional gene abundance; ${ }^{3}$ not analyzed for stable $\mathrm{NO}_{3}^{-}$isotopes.

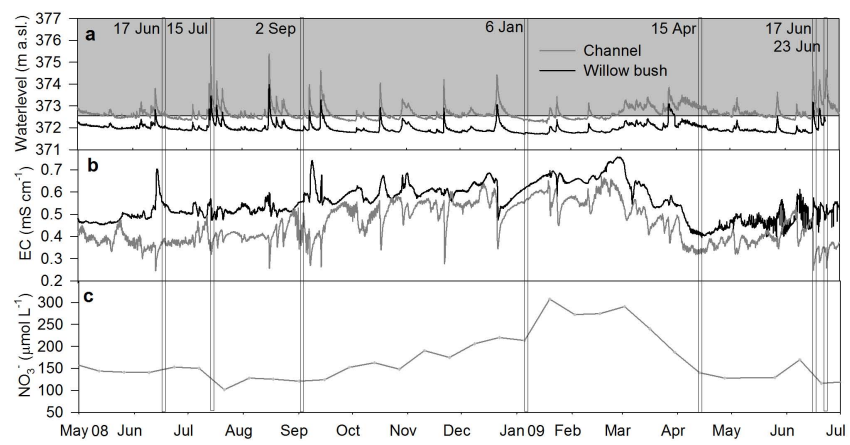

Fig. 2. Variations in water level (a) and electrical conductivity (EC) (b) in the channel and in the piezometer in willow bush (R041) from May 2008 until the end of June 2009 and bi-weekly $\mathrm{NO}_{3}^{-}$concentration in the river Thur (http://www.naduf.ch/daten.htm) (c). The gray area indicates the position of the overlying soil structure of the aquifer. Vertical bars designate the different sampling dates. Water level fluctuations in willow bush followed water level variations in the channel, reflecting high hydraulic connectivity. Electrical conductivity generally showed a slightly dampened and time-shifted signal in willow bush compared to the channel. During flood events in the periods June to October 2008 and May to July 2009, the electrical conductivity signal in willow bush was reverse to that of the channel.

analyzer (TOC-V CPH) using high-temperature catalytic oxidation (Benner and Strom, 1993). The accuracy of the analysis was $1.5 \%$. Concentrations of TN (dissolved and particulate inorganic and organic $\mathrm{N}), \mathrm{NO}_{3}^{-}$, nitrite $\left(\mathrm{NO}_{2}^{-}\right)$, and ammonium $\left(\mathrm{NH}_{4}^{+}\right)$were determined colorimetrically on a Technicon autosampler (DEV, 2004). The analytical errors were $5 \%$ for $\mathrm{TN}, 2.5 \%$ for $\mathrm{NO}_{2}^{-}$, and $6 \%$ for $\mathrm{NO}_{3}^{-} \cdot \mathrm{N}_{2} \mathrm{O}$ was quantified by headspace analysis on an Agilent $6890 \mathrm{~N}$ gas chromatograph (Jas, Germany) with an autosampler and a GS-Carbon PLOT column. $\mathrm{N}_{2} \mathrm{O}$ concentrations in the samples were calculated according to Weiss and Price (1980). The analytical error was $0.2-4.6 \%$. Dissolved $\mathrm{O}_{2}$ concen- trations were measured using the standard Winkler method (Grasshoff et al., 1999).

The stable $\mathrm{N}$ and $\mathrm{O}$ isotopic composition of dissolved $\mathrm{NO}_{3}^{-}$, providing information on major $\mathrm{N}$ transformation processes, was measured using the "denitrifier method" described in detail by Sigman et al. (2001) and Casciotti et al. (2002). $\mathrm{N}$ and $\mathrm{O}$ isotopic ratios were reported in the standard $\delta$ notation relative to atmospheric $\mathrm{N}_{2}$ for $\mathrm{N}$ and $\mathrm{V}$ SMOW for $\mathrm{O}$, respectively. Nitrate isotope measurements were standardized using the international $\mathrm{NO}_{3}^{-}$standards IAEA-N3 and USGS-34. The two-standard calibration allows accounting for $\mathrm{O}$-isotope scale compression due to instrument properties and $\mathrm{O}$-isotope exchange during bacterial conversion. Oxygen exchange was additionally monitored with ${ }^{18}$ O-enriched water standards (Casciotti et al., 2002) and was never greater than $5 \%$. Blank contribution was generally smaller than $1 \%$. The reproducibility of replicate analyses was typically $\pm 0.2 \%$ for $\delta^{15} \mathrm{~N}$ and $\pm 0.3 \%$ o for $\delta^{18} \mathrm{O}$. Net $\mathrm{N}$ and $\mathrm{O}$ isotope fractionation during $\mathrm{NO}_{3}^{-}$consumption in the riparian zone was approximated assuming Rayleigh distillation kinetics (Kendall and Caldwell, 1998).

\subsection{Functional gene abundance}

Deoxyribonucleic acid (DNA) was extracted from filters using Fast DNA Spinkit for soil (MP Biomedicals) and quantified using Sybr green I (Matsui et al., 2004). To estimate the denitrification potential of the microbial assemblage in the mobile phase along flow paths, we analyzed the abundance of the functional genes involved in the denitrification process $\left(\mathrm{NO}_{3}^{-}\right.$reductase genes nirK and nirS, and nitrous oxide reductase gene nos $Z$ ) by real-time PCR on a 7300 Real-Time PCR System (Applied Biosystems) with Kapa Sybr Fast qPCR mix (Kapa Biosysems). As qPCR standards, genomic DNA of pure cultures Pseudomonas fluorescence C7R12 (nirS), Azospirillum irakense DSM 11586 (nirK), and Pseudomonas stutzeri (nosZ) were used. The individual qPCR conditions and primers used are described in detail by 
Brankatschk et al. (2010). To avoid PCR inhibition, dilutions of $1: 16$ of the DNA template was found to be best for optimal detection. Copy numbers were calculated using the OPC method (Brankatschk et al., 2012) and the efficiencies of the samples were derived using the LinRegPCR program (version 11, Ruijter et al., 2009). Copy numbers were normalized to the amount of extracted DNA to reduce artifacts from sample filtration and DNA extraction. Copy numbers per ng DNA yield the proportion of the microbial community carrying the specific gene. The ratio of nosZ / $(n i r S+n i r K)$ was used to quantify the proportion of the denitrifying community that can carry out all steps of denitrification (including the reduction to $\mathrm{N}_{2}$ ). This approach was adapted from Philippot et al. (2009). The efficiency of the PCR reaction was $81 \%$ for $n i r S, 70 \%$ for $n i r K$, and $86 \%$ for nosZ. In the qPCR assay, each template was analyzed in triplicate, and some of the environmental samples were run with replicates of DNA extraction (April 2009: willow bush; 23 June 2009: channel, grass, and forest). The deviation for these replicates was 2 $27 \%$ of copy numbers $\mathrm{ng}^{-1}$ DNA for $\operatorname{nirS}, 2-29 \%$ for $\operatorname{nirK}$, and $6-33 \%$ for $n o s Z$.

\subsection{Nitrogen budget calculations}

$\mathrm{N}$ budgets were computed along flow lines for the different FPZs assuming that the river and the soil constitute the main sources of the $\mathrm{N}$ compounds, and that the river is directly connected to the individual FPZ to which river water is supplied (Fig. 1). River water enters the FPZ near the bank and is then transported with constant velocity along the flow path to the piezometer where the final concentration was monitored (Fig. 1a). The solute concentrations at the piezometers reflect the outflow concentration of the FPZ in this model. The difference between the compound/solute flux out of the FPZ $\left(J_{\mathrm{FPZ}}\right)$ and the sum of fluxes into the groundwater from the channel and the soil ( $J_{\text {CHANNEL }}$ and $J_{\text {SOIL }}$ ) indicate whether there is a loss or a gain of a $\mathrm{N}$-compound in a FPZ (Fig. 1b). A negative $\mathrm{N}$ budget indicates a loss of $\mathrm{N}$ by non-conservative processes that are not accounted for in the transport model, e.g. through microbial $\mathrm{N}$ dissimilation or plant assimilation. Positive values indicate additional inputs also not accounted for by the model, e.g. due to underestimation of the sources that are implemented in the model, or the production of dissolved inorganic $\mathrm{N}$ via mineralization of organic $\mathrm{N}$ along the flow path. Fluxes are given in $\mathrm{mol} \mathrm{d}^{-1}$ and were calculated as follows:

$J_{\text {SOIL }}=c_{\text {SOIL }} \times Q_{\text {SOIL }}$

$J_{\mathrm{CHANNEL}}=c_{\mathrm{CHANNEL}} \times Q_{\mathrm{CHANNEL}}$

$J_{\mathrm{FPZ}}=c_{\mathrm{FPZ}} \times Q_{\mathrm{FPZ}}$

with $Q_{\text {SOIL }}$ in $1 \mathrm{~d}^{-1}$ calculated from specific soil exfiltration rates $\left(q_{\text {SOIL }}\right.$ in $\left.1^{-2} \mathrm{~d}^{-1}\right)$ and FPZ length $(l)$ and width $(w)$ in $\mathrm{m}\left(Q_{\text {SOIL }}=q_{\text {SOIL }} \times l \times w\right)$. All model input data are listed in the Supplement (Table S1). Huber et al. (2012) applied the COUP numerical soil water and heat model (Jansson and Moon, 2001) in combination with measured soil properties and meteorological data monitored at the site for calculation of $q_{\mathrm{SOIL}} \cdot Q_{\mathrm{CHANNEL}}$ was calculated from groundwater flux data, $q_{\mathrm{FPZ}}$ (Darcy flux in $\mathrm{md}^{-1}$ ), adopted from the three-dimensional steady-state groundwater flow model developed by Diem et al. (2012) which is described above, and the length $(l)$ and height $(h)$ of the FPZ $\left(Q_{\mathrm{CHANNEL}}=q_{\mathrm{FPZ}} \times l \times h\right)$. By mass balance, $Q_{\mathrm{FPZ}}$ equals $Q_{\text {CHANNEL }}+Q_{\text {SOIL }}$. The data set on groundwater concentrations ( $c_{\mathrm{CHANNEL}}$ and $c_{\mathrm{FPZ}}$ in mol $1^{-1}$ ) used for budget calculations is based on the sampling campaigns during 20082009 described in this study and an additional sampling in May 2011 (not shown). For each FPZ, data from one selected piezometer was averaged for base to average discharge conditions $\left(<75 \mathrm{~m}^{3} \mathrm{~s}^{-1}\right)$ during spring and summer periods (Fig. 1). Soil concentration data $\left(c_{\text {SOIL }}\right.$ in $\left.\mathrm{moll}^{-1}\right)$ are described in Huber et al. (2012). Finally, the N fluxes were standardized to $\mu \mathrm{moll}^{-1} \mathrm{~d}^{-1}$ considering the effective FPZ volume (FPZ volume $\times$ porosity). The efficiency of the individual $\mathrm{FPZ}$ for $\mathrm{NO}_{3}^{-}$removal was calculated after Dhondt et al. (2006): efficiency $=\left(J_{\mathrm{SOIL}}+J_{\mathrm{CHANNEL}}-J_{\mathrm{FPZ}}\right) /\left(J_{\mathrm{SOIL}}+\right.$ $\left.J_{\text {CHANNEL }}\right) \times 100 \%$. Monte Carlo simulations were run with $10^{6}$ iterations on Matlab (7.8.0, The MathWorks) for mean and error estimations.

\section{Results}

\subsection{Hydrodynamics}

At all sampling campaigns, the water level of the river Thur was higher than the groundwater head (Fig. 2a) and the river was losing water into the saturated riparian zone (Fig. 1a). The two main piezometer transects, installed in the unconfined aquifer at the restored and the channelized section, do not reflect the subsurface flow direction (Fig. 1a). As a consequence, the individual piezometers and FPZs are not directly connected by the hydrological flow. With exception of the forest zone, the river water infiltrates directly into the FPZ (Fig. 1). The hydrological regime of the river strongly differed among the sampling campaigns (Table 1), and temporal water level changes in the channel reflect these variations (Fig. 2a). In the willow bush zone, the water level responded almost instantaneously to changes in the river, indicating a good hydraulic connection between river and groundwater, and during peak events groundwater reached the base of the overlying loamy soil at $\sim 372.8 \mathrm{~m}$ a.s.l. (Fig. 2a). A similar trend in water table fluctuation was described by Vogt et al. (2010) for piezometers in the grass, forest, and pasture zones. In the willow bush zone, the electrical conductivity time series showed a slightly damped and time-shifted river signal from November 2008 until April 2009 (Fig. 2b), 
reflecting solute transport from the river to the aquifer. Additionally, elevated electrical conductivity peaks, reverse to the diluted river signal, were observed during flood events in June 2008, September 2008, and May to July 2009 (Fig. 2a).

\subsection{Spatio-temporal variability of $\mathrm{NO}_{3}^{-}, \mathrm{NO}_{2}^{-}$, and $\mathrm{N}_{2} \mathrm{O}$ concentrations}

The river channel was characterized by high $\mathrm{NO}_{3}^{-}$concentrations (mean $139 \pm 74 \mu \mathrm{moll}^{-1}$ ) which were marginally diluted during flood events and exhibited a marked seasonality, with higher concentrations in winter than in summer (Figs. 2c and 3a, b) (http://www.naduf.ch/daten.htm). Overall, $\mathrm{NO}_{3}^{-}$represented the main fraction of TN $(92 \pm 15 \%)$, and $\mathrm{NO}_{3}^{-}$concentrations were negatively (but not significantly) correlated with river discharge (Pearson correlation coefficient: $r=-0.32$, significance value: $p>0.05$ ). Also, the inverse correlation with temperature was relatively weak, even if significant $(r=-0.51, p<0.01)$. Both, $\mathrm{NO}_{2}^{-}$and $\mathrm{N}_{2} \mathrm{O}$ concentrations in the river were low $(0.5 \pm 0.6$ and $0.02 \pm 0.005 \mathrm{moll}^{-1}$, respectively, Fig. 3c-e). Analysis of variance (ANOVA, SPSS 17.0, IBM) could not resolve significant differences in $\mathrm{NO}_{3}^{-}$concentrations among the different riparian zones $(p>0.05)$. Nevertheless, different trends for the individual zones could be discerned for different flow regimes (Fig. 3a and b). Gravel and grass zone $\mathrm{NO}_{3}^{-}$concentrations correlated with $\mathrm{NO}_{3}^{-}$concentrations in the river $(r=$ $0.99, p<0.01$ and $r=0.78, p<0.05$, respectively). During flood events, $\mathrm{NO}_{3}^{-}$levels at the groundwater piezometers close to the river were lower than at the more distant ones, simply because $\mathrm{NO}_{3}^{-}$concentrations were lowered in river water during these events (Fig. 3a). In the willow bush zone, the $\mathrm{NO}_{3}^{-}$concentrations were only weakly correlated with those in the channel $(r=0.33, p<0.05)$, and during base flow, the lowest $\mathrm{NO}_{3}^{-}$concentration of all FPZs was recorded (Fig. 3b). In contrast to $\mathrm{NO}_{3}^{-}$, the highest $\mathrm{NO}_{2}^{-}$and $\mathrm{N}_{2} \mathrm{O}$ concentrations were measured during base flow in the willow bush zone (Fig. 3d and e). In samples from the forest, the $\mathrm{NO}_{3}^{-}$concentrations were essentially invariant, with a mean value of $136 \pm 33 \mu \mathrm{moll}^{-1}$. The forest zone also exhibited elevated $\mathrm{N}_{2} \mathrm{O}$ and slightly elevated $\mathrm{NO}_{2}^{-}$concentrations during base/average flow, compared to the other riparian zones. The pasture zone in the channelized river section exhibited relatively invariant $\mathrm{NO}_{3}^{-}$concentrations, and no elevated $\mathrm{NO}_{2}^{-}$ concentrations were observed.

\subsection{Nitrogen budgets for individual riperian zones}

Based on budget calculations for base and average flow conditions of the river, most of the $\mathrm{NO}_{3}^{-}$originated from infiltrating channel water, whereas the contribution of soil $\mathrm{NO}_{3}^{-}$ to the groundwater was low in the grass and willow bush zones $(1 \pm 1.2$ and $0.5 \pm 0.6 \%$, respectively), and higher in the forest zone $(10.6 \pm 9.3 \%)$. For all FPZs, model results revealed a net $\mathrm{NO}_{3}^{-}$loss (Fig. 4a). The highest volu-

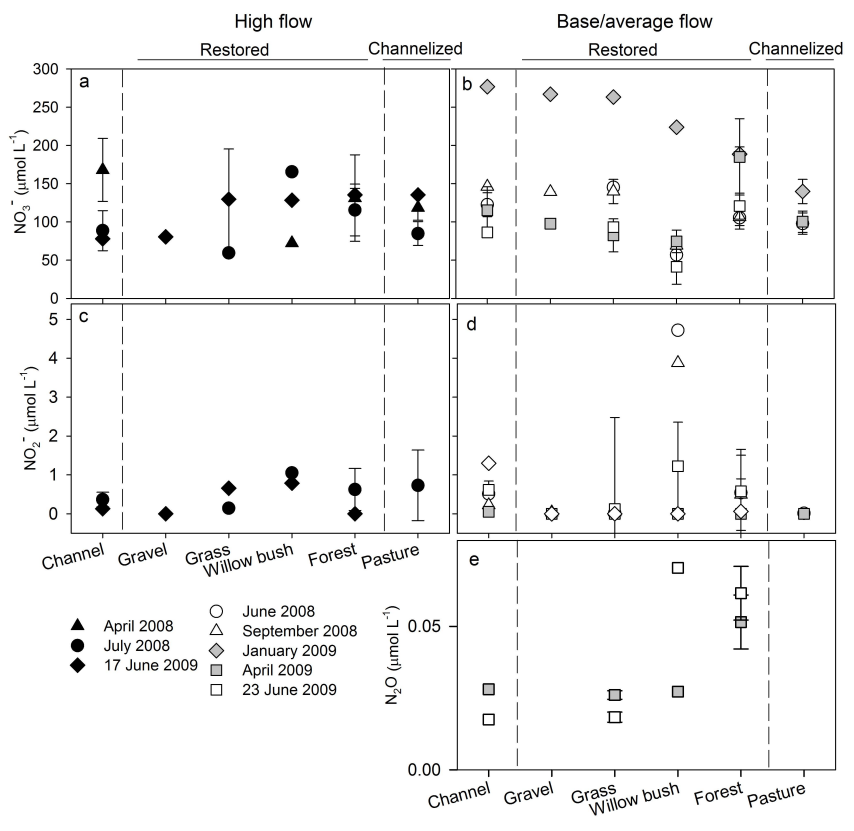

Fig. 3. $\mathrm{NO}_{3}^{-}, \mathrm{NO}_{2}^{-}$and dissolved $\mathrm{N}_{2} \mathrm{O}$ concentrations in different riparian zones during high discharge $(\mathbf{a}, \mathbf{c})$ and base to average discharge of the river Thur (b, d, e). Values from piezometers located in the same riparian zone were averaged, and error bars represent standard deviations $(n>2)$ or average deviations $(n=2)$.

metric $\mathrm{NO}_{3}^{-}$removal rates were found in the willow bush zone. Grass also exhibited increased rates, but with high model error and the lowest $\mathrm{NO}_{3}^{-}$removal efficiency of all zones. A small $\mathrm{NO}_{2}^{-}\left(0.1-0.5 \mu \mathrm{mol}^{-1} \mathrm{~d}^{-1}\right)$ and $\mathrm{N}_{2} \mathrm{O}(0.01-$ $\left.0.02 \mu \mathrm{mol} \mathrm{l}^{-1} \mathrm{~d}^{-1}\right)$ production was observed in the willow bush and the forest zones. A loss of $\mathrm{NH}_{4}^{+}$was observed in all riparian zones $\left(-0.2\right.$ to $\left.-1.1 \mu \mathrm{moll}^{-1} \mathrm{~d}^{-1}\right)$. Extrapolation to the scale of the total restored riparian aquifer revealed that the forest zone contributed most to total $\mathrm{NO}_{3}^{-}$ removal (Fig. 4b). For the pasture zone, the volume of the total restored aquifer was used for scaling, which allowed a direct comparison between the restored and the channelized section. $\mathrm{NO}_{3}^{-}$removal rates were significantly higher (t-test: $p<0.001)$ for the restored than for the channelized section (Fig. 4).

\subsection{Nitrate isotope ratios}

The river water, as well as the groundwater in the adjacent gravel and grass zones exhibited the lowest $\delta^{15} \mathrm{~N}$ and $\delta^{18} \mathrm{O}$ values for $\mathrm{NO}_{3}^{-}(\sim 9.5$ and $\sim 2.5 \%$, respectively) among the different zones (Fig. 5). The highest $\mathrm{NO}_{3}^{-} \delta^{15} \mathrm{~N}$ and $\delta^{18} \mathrm{O}$ values were observed in the willow bush zone. Taking into account the complete groundwater data set, a linear relationship exists between $\mathrm{NO}_{3}^{-} \delta^{15} \mathrm{~N}$ and $\delta^{18} \mathrm{O}\left(R^{2}=\right.$ 0.87 , slope $=0.572, p<0.01$ ). The apparent $\mathrm{N}$ (and $\mathrm{O}$ ) isotope effects $\varepsilon_{\mathrm{N}}\left(\varepsilon_{\mathrm{O}}\right)$ were derived by plotting the $\delta^{15} \mathrm{~N}$ $\left(\delta^{18} \mathrm{O}\right)$ against the natural logarithm of the residual $\mathrm{NO}_{3}^{-}$ 


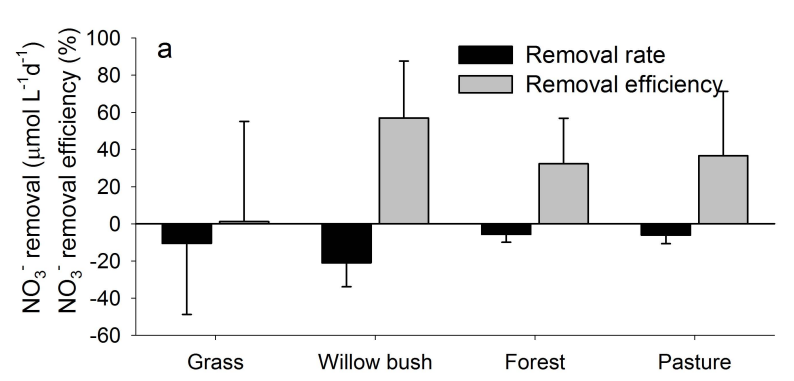

。

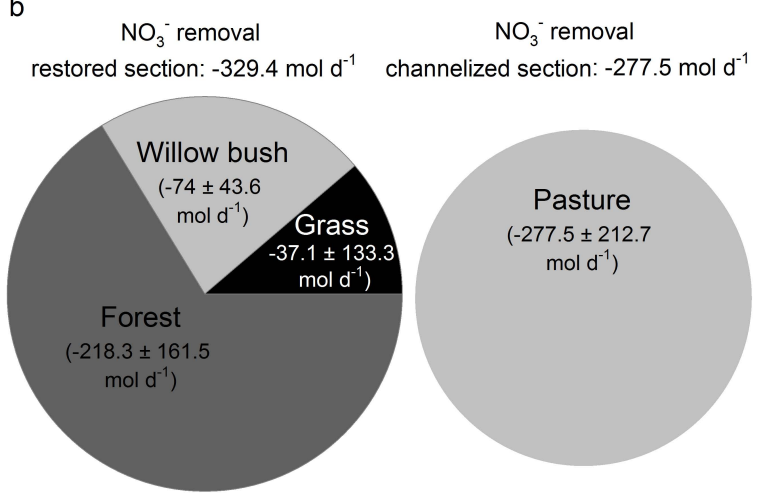

Fig. 4. (a) Average $\mathrm{NO}_{3}^{-}$removal rates and efficiencies with standard deviations $( \pm)$ derived by Monte Carlo simulations within a specific FPZ during base/average flow conditions of the river during spring to summer. The negative rate values designate loss from the groundwater, most probably due to dissimilar consumption by denitrification or due to plant uptake. (b) Nitrate loss rates ( \pm standard deviations from Monte Carlo simulations) for the individual FPZs are normalized to the whole restored river section at base/average flow conditions of the river, and during the spring to summer period. For better comparison, we used the same aquifer volume for the channelized pasture area as for the total restored aquifer.

concentration according to Mariotti et al. (1981), where the slope of the linear regression line approximates $\varepsilon_{\text {app }}: \delta^{15} \mathrm{~N}$ $\left(\text { or } \delta^{18} \mathrm{O}\right)_{\text {reactant }}=\delta^{15} \mathrm{~N}\left(\text { or } \delta^{18} \mathrm{O}\right)_{\text {initial }}-\varepsilon\left(\ln \left[\mathrm{NO}_{3}^{-}\right]\right)$. For the groundwater data of the restored river section, these Rayleigh graphs yielded significant linear correlations for June $\left(R^{2}=0.94\right.$, slope: apparent enrichment factor $\varepsilon_{\mathrm{N}}=$ $-22 \%, p<0.01)$ and September $2008\left(R^{2}=0.75\right.$, slope: $\left.\varepsilon_{\mathrm{N}}=-13.2 \%, p<0.01\right)$ and a moderately significant linear relationship for 23 June $2009\left(R^{2}=0.42\right.$, slope: $\varepsilon_{\mathrm{N}}=$ $-6.6 \%, p<0.05)$ (Fig. 6). Apparent enrichment factors for ${ }^{18} \mathrm{O}$ were $-14.9,-10.4$, and $-4 \%$ for June and September 2008 , and 24 June 2009, respectively. The data for the linear regression models passed tests for normality (Shapiro-Wilk test) and for constant variance.

\subsection{Functional gene abundance}

The amount of DNA extracted from water samples was generally lower in April 2009 than in June 2009, with highest concentrations in the river water in both seasons (data not shown). The nirK, nirS, and nosZ genes involved in denitrifi-

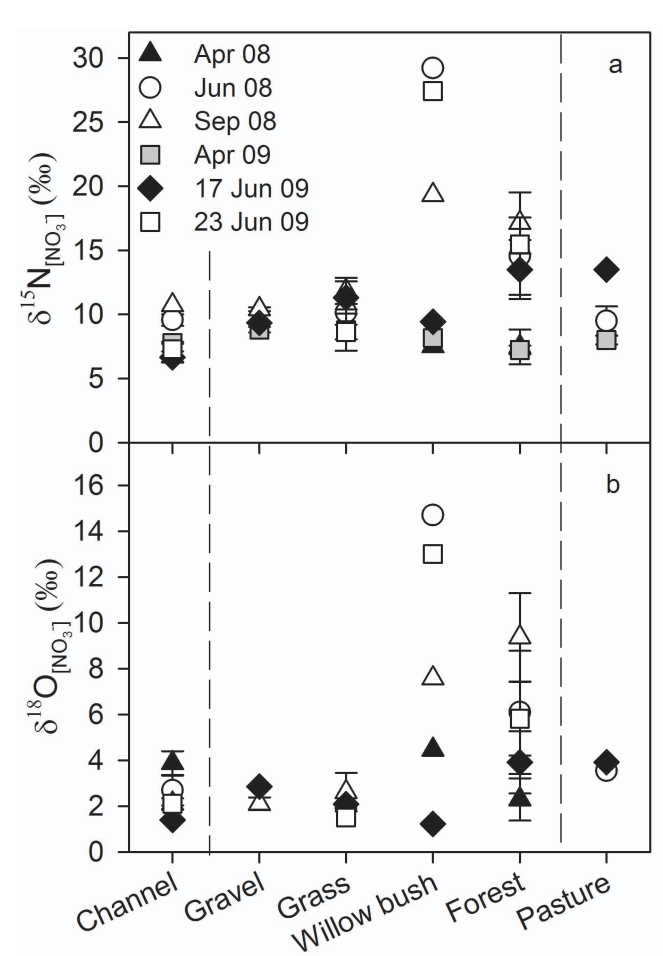

Fig. 5. Stable $\mathrm{N}(\mathbf{a})$ and $\mathrm{O}(\mathbf{b})$ isotope ratios $\left(\delta^{15} \mathrm{~N}, \delta^{18} \mathrm{O}\right)$ of residual $\mathrm{NO}_{3}^{-}$in different riparian zones from all sampling campaigns. In June and September 2008, as well as in June 2009 one week after a flooding event, an enrichment of ${ }^{15} \mathrm{~N}$ and ${ }^{18} \mathrm{O}$ in the $\mathrm{NO}_{3}^{-}$was observed in willow bush. Values from piezometers located in the same zone were averaged and error bars represent standard deviations $(n>2)$ or average deviations $(n=2)$.

cation were abundant throughout the riparian aquifer, with the nirK gene generally showing the highest contribution (Fig. 7). The nirS and nosZ genes were significantly correlated $(r=0.97, p<0.01)$ for both sampling campaigns. River water and groundwater of the grass zone generally exhibited the lowest relative abundance of nirS and nos Z genes. High abundances of nirS and nos $Z$ genes, relative to the other zones, were observed in the willow bush zone. In the forest zone, nirS and nos $Z$ genes were also elevated when compared to the river water samples. The nosZ / (nirS + nirK) ratio, which indicates the proportion of the denitrifying community that can carry out complete denitrification (including the reduction to $\mathrm{N}_{2}$ ), was highest in the willow bush followed by the forest zone in both sampling campaigns (Fig. 7). The variations can primarily be attributed to changes in $\operatorname{nirS}$ and nos $Z$ gene abundance. No samples were analyzed for the gravel and pasture groundwater.

\subsection{Spatio-temporal variability of TOC and $\mathrm{O}_{2}$ concentrations}

In the river Thur, TOC concentrations were lower during base/average flow conditions than during high flow (except 


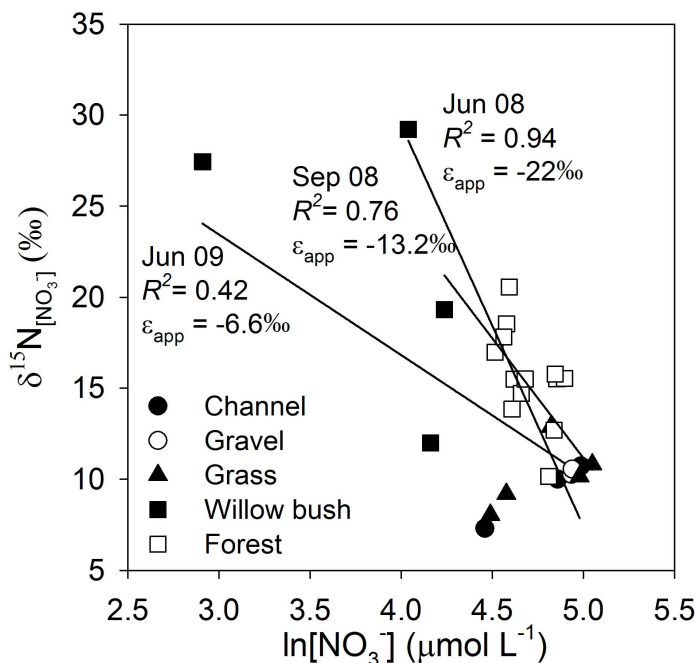

Fig. 6. Rayleigh plots for $\delta^{15} \mathrm{~N}$ from June and September 2008 and 23 June 2009 indicate that $42-94 \%$ of the covariance between $\ln \left[\mathrm{NO}_{3}^{-}\right]$and $\delta^{15} \mathrm{~N}$ can be explained by biological fractionation. The slope of the regression lines indicates the apparent (or community) enrichment factors of $\mathrm{NO}_{3}^{-}$removal.

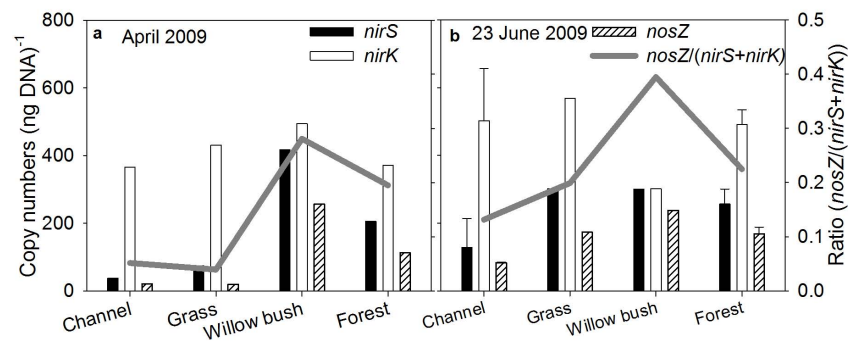

Fig. 7. Abundance of the functional genes nirS, nirK, and nos $Z$ in April 2009 (a) and 23 June 2009 (b) in the different riparian zones. The potential of the denitrifying community to carry out complete denitrification (from $\mathrm{NO}_{3}^{-}$to $\mathrm{N}_{2}$ ) is indicated by the ratio of nosZ / (nirS + nirK). Values from piezometers located in the same zone were averaged and error bars represent standard deviations $(n>2)$ or average deviations $(n=2)$.

the sampling on 23 June 2009, which took place during a declining flood and had TOC concentrations that were similar to those at the beginning of the flood on 17 June 2009) (Fig. 8a and b). The TOC concentrations in the groundwater of the gravel and grass zones were closely correlated with those in the river $(r=0.99, p<0.01$ and $r=0.87$, $p<0.05$, respectively). In the willow bush zone, TOC concentrations were the highest during flood events. The most invariant TOC concentrations (at low levels) among all zones were observed in the forest and the pasture zones (Fig. 8a and $\mathrm{b}$ ). There, the OC dynamics seem to be decoupled from $\mathrm{OC}$ fluctuations in proximity to the river corridor. The $\mathrm{OC}$ of the soil water, measured by Huber et al. (2012), in the different FPZs was lowest in the willow bush zone (533 $\pm 70-$

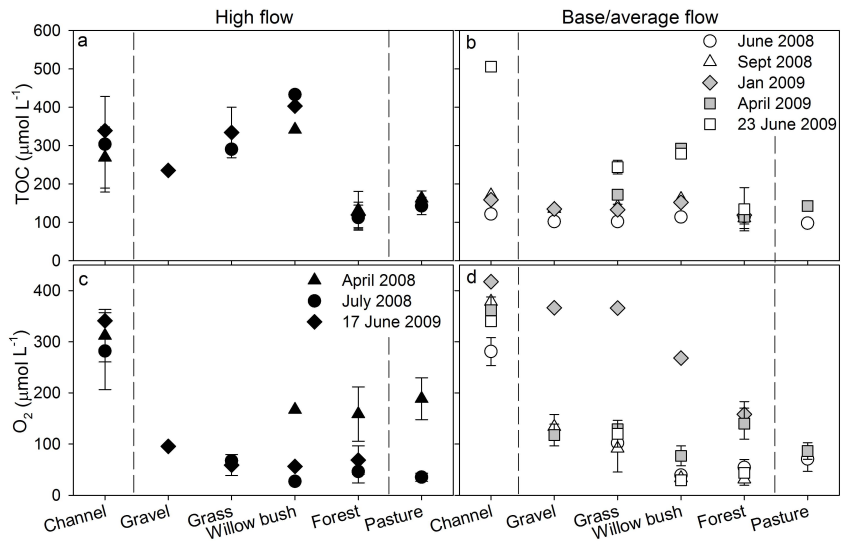

Fig. 8. TOC and $\mathrm{O}_{2}$ concentrations in different riparian zones during high discharge $(\mathbf{a}, \mathbf{c})$ and base to average discharge of the river Thur $(\mathbf{b}, \mathbf{d})$. Values from piezometers located in the same riparian zone were averaged and error bars represent standard deviations $(n>2)$ or average deviations $(n=2)$.

$\left.605 \pm 45 \mu \mathrm{mol}^{-1}\right)$ and highest in the forest zone $(743 \pm 40$ $-983 \pm 299 \mu \mathrm{moll}^{-1}$ ). Dissolved $\mathrm{O}_{2}$ concentrations in the river Thur were close to saturated levels $\left(280-420 \mu \mathrm{moll}^{-1}\right)$ (Fig. 8c and d), but within the first few meters distance from the channel, $\mathrm{O}_{2}$ concentration in the groundwater dropped to $25 \mu \mathrm{mol}^{-1}$ until the willow bush FPZ. In all locations, oxygen concentrations were highest during winter low flow (January 2009) and/or during early spring flooding (April 2008).

\section{Discussion}

\subsection{N sources and net losses in individual riparian zones}

The river Thur represents the main water supply for the riparian groundwater of all FPZs (Vogt et al., 2010), mirrored in the high hydraulic and hydrological connectivity in the riparian aquifer (Fig. 2a and b). Moreover, the channel constitutes the main $\mathrm{N}$ source to the groundwater as the river Thur receives high $\mathrm{NO}_{3}^{-}$inputs from diffuse agricultural sources (Abbaspour et al., 2007), but inputs from the soil can also significantly contribute to the groundwater $\mathrm{N}$ pool $(\sim 11 \%$ in the forest zone) (Huber et al., 2012).

Our data suggest that the FPZs of the river Thur greatly differ in their capacity for net $\mathrm{NO}_{3}^{-}$removal from infiltrating river water during base to average runoff (Fig. 3). Low concentrations of $\mathrm{NO}_{3}^{-}$were detected in the willow bush zone, indicating a removal of the $\mathrm{NO}_{3}^{-}$supplied by the river. From $\mathrm{N}$ budget calculations, we found that the willow bush zone can be considered a hot spot for $\mathrm{NO}_{3}^{-}$removal during base and average flow, exhibiting the highest removal rates per unit volume and the highest fixed $\mathrm{N}$ removal efficiency (Fig. 4a). The lowest $\mathrm{N}$ removal efficiency was calculated for the grass zone. However, in this zone, a relatively large variability in $\mathrm{NO}_{3}^{-}$concentrations, in combination with 
small concentration differences with respect to the channel and a relatively fast groundwater flow, resulted in large errors for model-based estimates of $\mathrm{N}$ removal rates (Fig. 4a, Table S1). Taking the spatial extent of the different riparian zones into account, the forest contributes most to the total riparian aquifer $\mathrm{NO}_{3}^{-}$removal (Fig. 4b). This supports the findings by Findlay et al. (2011), who found that large areas with comparatively low denitrification activity (cool matrix) can actually remove more $\mathrm{NO}_{3}^{-}$than rather constrained hot spots of high denitrification rates. The budget calculations also revealed that the forest groundwater receives more soil $\mathrm{NO}_{3}^{-}$than the other riparian zones $(\sim 11 \%)$. Comparing the pasture in the channelized part of the river with the restored aquifer, our data demonstrate that the pasture played a less important role in the ecosystem removal of $\mathrm{NO}_{3}^{-}$(Fig. 4b). It needs to be noted that the model disregards $\mathrm{NO}_{3}^{-}$loss at the river-aquifer boundary and assumes constant groundwater flow and transformation rates, which might not entirely reflect the reality. Especially for the forest zone with the longest infiltration path, this may create additional model uncertainties that were not accounted for.

\section{$4.2 \mathrm{NO}_{3}^{-}$removal processes}

In riparian aquifers, $\mathrm{NO}_{3}^{-}$removal is mainly attributed to denitrification or assimilation by riparian vegetation (Dhondt et al., 2003), although a decrease in $\mathrm{NO}_{3}^{-}$concentration can also be related to mixing with $\mathrm{NO}_{3}^{-}$-depleted groundwater (Craig et al., 2010). In the willow bush and forest zones of the river Thur aquifer, the increased concentrations of $\mathrm{NO}_{2}^{-}$ and $\mathrm{N}_{2} \mathrm{O}$ (Fig. 3d and e), two intermediate products of denitrification, imply that denitrification is responsible for the apparent $\mathrm{NO}_{3}^{-}$removal. Further support for denitrification as an important $\mathrm{N}$ loss term is provided by the functional gene analyses. The higher relative abundance of genes involved in denitrification in the willow bush and forest zones indicate that here the microbial denitrification potential was higher than in the other riparian zones (Fig. 7). It needs to be noted that we have analyzed the suspended microbial community, which only partially reflects the total subsurface community and does not include microbes in biofilms. In a strict sense, we cannot say a priori that gene evidence is representative of the in situ conditions, as microbes found in one FPZ could in fact originate from another FPZ or the river. In a parallel study at the same field site, however, Peter et al. (2012) found that the suspended microbial community is actively growing in the groundwater. Therefore, the gene abundances in this riparian groundwater seem to reflect local and, to a lesser extent, upstream environmental conditions. They may be used as an indicator for local microbial processes in the groundwater. We found that in the willow bush zone, the relative contribution of the nos $Z$ gene to the total number of genes involved in denitrification was highest compared to all other zones, independent of whether $\mathrm{NO}_{3}^{-}$concentration was high or low. It has been shown that the nos $Z$ abundance positively correlates with potential denitrification rates (Brankatschk et al., 2010; Hallin et al., 2009). Furthermore, it indicates the dominance of microbes that are capable of carrying out complete reduction of $\mathrm{NO}_{3}^{-}$to $\mathrm{N}_{2}$ (Fig. 7).

The patterns of ${ }^{15} \mathrm{~N}$ and ${ }^{18} \mathrm{O}$ in the residual $\mathrm{NO}_{3}^{-}$in groundwater helped to further discern physical mixing, plant uptake and denitrification as potential mechanisms explaining the low $\mathrm{NO}_{3}^{-}$concentrations. We can rule out that mixing with water sources that are tagged with a high- $\delta^{15} \mathrm{~N}\left(\delta^{18} \mathrm{O}\right)$ $\mathrm{NO}_{3}^{-}$isotope signature contributed to the observed elevation in the $\mathrm{NO}_{3}^{-}$delta values in the willow bush zone. Leaching of $\mathrm{NO}_{3}^{-}$from willow bush soil into the groundwater was negligible $(\sim 0.5 \%)$, and the soil water displayed $\delta^{15} \mathrm{~N}$ values that were only slightly (if at all) elevated over the $\mathrm{NO}_{3}^{-} \delta^{15} \mathrm{~N}$ in the river Thur and markedly lower than the observed $\delta^{15} \mathrm{~N}$ values for the willow bush zone $(9.5 \pm 2.9 \%$, personal communication by Benjamin Huber). Furthermore, simple mixing with old $\mathrm{NO}_{3}^{-}$-depleted groundwater is unlikely, given a very short water residence time of only 4.5 days for this zone (Vogt et al., 2010). Plotting the $\delta^{15} \mathrm{~N}$ of $\mathrm{NO}_{3}^{-}$versus $1 / \mathrm{NO}_{3}^{-}$ did not reveal any evidence for mixing (plot not shown). In fact, the logarithmic correlation between $\mathrm{NO}_{3}^{-} \delta^{15} \mathrm{~N}$ and $\mathrm{NO}_{3}^{-}$ concentration provides a strong argument against conservative mixing and for biological removal (Mariotti et al., 1981) (Fig. 6). The calculated average $\Delta \delta^{18} \mathrm{O}: \Delta \delta^{15} \mathrm{~N}$ enrichment ratio was 0.57 . Similar values were reported for denitrification from another riparian zone (0.59; Cey et al., 1999) and other freshwater systems (0.6; Lehmann et al., 2003).

The relative contribution of denitrification and plant assimilation to the community $\mathrm{N}$ isotope fractionation can be approximated if the end member $\mathrm{N}$ isotope effects for denitrification and assimilation are known, respectively (Dhondt et al., 2003; Lund et al., 1999). Adopting the enrichment factors reported by Dhondt et al. (2003) for plant uptake $(\sim-4 \%$ o) and denitrification in groundwater $(\sim-23 \%)$, and based on the average $\mathrm{N}$ isotope enrichment factor of $-14 \%$ o determined in this study, we can calculate that on average $62 \%$ the observed $\mathrm{NO}_{3}^{-}$deficiency can be attributed to denitrification, while the remaining $37 \%$ was due to plant uptake. Variation in the community $\mathrm{N}$ isotope effect for $\mathrm{NO}_{3}^{-}$removal suggests, however, that this partitioning varied significantly. Using the same approach, we estimate that denitrification contributed $98 \%$ in June 2008, $68 \%$ in September 2008, and $21 \%$ in June 2009 to the $\mathrm{NO}_{3}^{-}$removal. Thus, in this riparian aquifer, $\mathrm{NO}_{3}^{-}$removal seems to primarily take place through denitrification and to a lesser extent through plant uptake. Interestingly, both processes seem to be constrained to the willow bush and, to a lesser extent, the alluvial forest zone during base and average flow conditions. 


\subsection{Vegetation-soil-groundwater coupling: the role of habitats and flood events}

At the restored Thur site, gravel bars and grass strips close to the main channel were mainly influenced by OC introduced with infiltrating river water (Fig. 8) and exhibited no apparent denitrification activity. We assume that the subsurface water residence times were too short and OC supply insufficient for the development of denitrifying conditions (Malard et al., 2002). In the willow bush zone, where flood events result in enhanced OC availability (Fig. 8) (Peter et al., 2012), a denitrification hot spot can be formed. The alluvial forest and the pasture in the channelized river section exhibit intermediate TOC concentrations with the smallest temporal concentration changes among all groundwater samples and lower denitrification rates (Fig. 4a). Hence, in the Thur aquifer, as a limiting substrate, OC appears as the main factor that controls microbial efficiency in general and $\mathrm{NO}_{3}^{-}$removal in particular (Mayer et al., 2010).

The $\mathrm{NO}_{3}^{-}$removal hot spot willow bush was densely populated with Salix viminalis. These pioneer species are closely associated with enhanced heterotrophic growth in the rhizosphere (Lalke-Porczyk et al., 2009) through high belowground carbon production (de Neergaard et al., 2002) and known for their high $\mathrm{NO}_{3}^{-}$removal capacity (Aronsson and Perttu, 2001; Elowson, 1999). In a companion study at this field site, the OC composition in the willow bush zone groundwater could clearly be related to bioavailable soil- and vegetation-derived OC (Peter et al., 2012). Therefore, we assume that willow plants are a considerable source of bioavailable OC for the saturated subsurface zone. Here, it may directly stimulate microbial respiration, leading to the development of suboxic conditions, and potentially initiate denitrification. Indeed, a recent study by Clinton et al. (2010) suggests that differences in OC bioavailability in a riparian subsurface flow is related to the type of vegetation cover. Similarly, Schade et al. (2001) observed a direct effect of vegetation cover on groundwater denitrification and proposed that the organic substrates that drive denitrification originated from plant production (Gift et al., 2010).

Variations in water table can foster interactions of the groundwater with the root zone of the riparian vegetation. Usually roots do not grow into the saturated zone, but in riparian systems, roots may be submerged during high water periods (Dosskey et al., 2010). The vertical root distribution and density of Salix sp. in alluvial environments has a tendency for increased growth towards the groundwater table with more distance from the river (Pasquale et al., 2012). Flooding raises the water table by $1-2 \mathrm{~m}$ towards the soil horizon of the willow bush zone (Fig. 2a) and may stimulate $\mathrm{NO}_{3}^{-}$removal through denitrification by connecting the $\mathrm{NO}_{3}^{-}$-rich groundwater with the bioavailable $\mathrm{OC}$ pool of the overlying soil and root zone. Inundation of the willow plants occurs only at a discharge $>300 \mathrm{~m}^{3} \mathrm{~s}^{-1}$, which is a rather rare event (1-2 per year) and might therefore not have a relevant effect on the observations in this study. In the willow bush zone, the electrical conductivity measurements indicated high ionic content in the water during periods of high runoff and low conductivity in the river (Fig. 2b and Vogt et al., 2010). Conductivity peaks can be explained by the leaching of high conductivity and, at the same time, OC-rich soil water (Huber et al., 2012) into the groundwater. Introduction of bioavailable $\mathrm{OC}$ stimulates microbial $\mathrm{CO}_{2}$ production, resulting in an increase in the electrical conductivity through ion dissolution. These flood-related conductivity peaks were mainly observed during the vegetation period (Fig. 2). Therefore, we assume that it is the root-derived OC that stimulates microbial activity and ultimately leads to an increased conductivity signal in the groundwater during flood events. This strong river-groundwater and soil-groundwater coupling at the willow bush zone facilitates substrate input to the subsurface, and may ultimately set the optimal conditions for the development of a $\mathrm{N}$ turnover hot spot in the post-flooding period.

Low $\mathrm{NO}_{3}^{-}$concentrations and enrichment of the heavier $\mathrm{NO}_{3}^{-}$isotopologues in the willow bush zone was observed always during the vegetation period (Fig. 5). In the winter/early spring period (April 2008 and January and April 2009), the groundwater was characterized by low temperatures $(0.5-$ $10^{\circ} \mathrm{C}$ ) and high $\mathrm{O}_{2}$ concentrations (Fig. 8b), indicating reduced microbial activity, consistent with no significant ${ }^{15} \mathrm{~N}$ $\left({ }^{18} \mathrm{O}\right)$ enrichment in the $\mathrm{NO}_{3}^{-}$pool. Also, the $\mathrm{N}$ isotopic data suggest that in the Thur riparian aquifer little denitrification and plant uptake occurred during flooding (Fig. 3 and 5), despite substantial $\mathrm{NO}_{3}^{-}$supply to the groundwater and intense contact of the groundwater with the root zone (Fig. 2a) providing bioavailable organic substrate. Flood events increase the groundwater flow velocity and can substantially decrease the actual contact time with the roots of the riparian vegetation and with the microbial "denitrifier" community, leading to diminished $\mathrm{NO}_{3}^{-}$removal. One week post flooding, $\mathrm{NO}_{3}^{-}$ and TOC concentrations were substantially reduced in the willow bush zone (Fig. 3 and 8) and the residual $\mathrm{NO}_{3}^{-}$was enriched in the heavy $\mathrm{N}$ and $\mathrm{O}$ isotopes (Fig. 5), suggesting intense post-flood $\mathrm{NO}_{3}^{-}$removal through denitrification triggered by the OC spike during the flood event and, to a lesser degree, plant $\mathrm{NO}_{3}^{-}$uptake by Salix viminalis.

\section{Concluding remarks and implications for restoration of riparian zones}

In a dynamic restored river system like at the river Thur, spatial heterogeneity translates into different FPZs with contrasting $\mathrm{NO}_{3}^{-}$removal potential. Both hot spots and cold matrices contribute to the enhanced $\mathrm{NO}_{3}^{-}$removal capacity through denitrification and plant uptake compared to the channelized riparian site. The rates of $\mathrm{NO}_{3}^{-}$removal of $\sim 21 \mu \mathrm{mol} \mathrm{N}{ }^{-1} \mathrm{~d}^{-1}\left(\sim 215 \mathrm{~kg} \mathrm{Nha}^{-1} \mathrm{yr}^{-1}\right)$ were similar to values reported in previous studies (Baker and Vervier, 2004; 
Mengis et al., 1999). The functioning of the willow bush hot spot as an efficient $\mathrm{NO}_{3}^{-}$filter is governed by hydraulic and biogeochemical conditions: Periodic flooding transports soil- and root-derived organic matter into the groundwater, and strong hydraulic connectivity ensures $\mathrm{NO}_{3}^{-}$supply. The biogeochemical $\mathrm{N}$-uptake by intense plant growth (Clement et al., 2003) probably also contributed to $\mathrm{NO}_{3}^{-}$elimination. Denitrification not only removes $\mathrm{NO}_{3}^{-}$from the system but can also be a considerable source of the greenhouse gas $\mathrm{N}_{2} \mathrm{O}$, especially in systems that are prone to frequent perturbations, for example due to sudden flood events. The latter may episodically provide $\mathrm{O}_{2}$ to the subsurface, thereby inhibiting $\mathrm{N}_{2} \mathrm{O}$ reduction (Naqvi et al., 2000; Verhoeven et al., 2006; Codispoti et al., 2001). However, the generally low $\mathrm{N}_{2} \mathrm{O}$ concentrations in the groundwater (Fig. 3e) translate into low production rates (Sect. 3.3) compared to rates from other systems (e.g. Kim et al., 2009; Mengis et al., 1996).

For a successful $\mathrm{N}$ monitoring in the groundwater of a restored site, the spatial and temporal investigation of $\mathrm{NO}_{3}^{-}$ concentration and its isotopic composition proved to be very powerful. This study emphasizes that successful river restoration and its functional assessment should consider the multi-dimensional linkages of alluvial groundwater systems. We recommend enhancing the environmental heterogeneity by configuring distinct riparian zones, or by allowing the occurrence of a natural geomorphic and vegetation succession. For example, we demonstrate here the value of a pioneer plant-dominated zone with regards to recharge of the soil OC inventory and the stimulation of $\mathrm{NO}_{3}^{-}$removal in the water-saturated zone. Willows are among the main colonists of alluvial environments with open and wet habitats $(\mathrm{Ku}-$ zovkina and Volk, 2009) and can be considered as unique hydrological features of riparian systems. When established they can endure extreme water table fluctuations. Such flood events are necessary to fully exploit the soil-groundwater connection and to develop optimal conditions for a denitrification hot spot. Overall, this study illustrates that the interactions between ecological and hydrological processes and riparian morphology should be taken into consideration in future restoration measures.

\section{Supplementary material related to this article is available online at: http://www.biogeosciences.net/9/ 4295/2012/bg-9-4295-2012-supplement.pdf.}

Acknowledgements. We are grateful to Marco Baumann and Andreas Scholtis from the Agency for the Environment, Canton Thurgau, for their continuous support and the excellent collaboration within this research project. Alessandro Brovelli (EPFL), Jörg Luster and Benjamin Huber (WSL) helped to set up the budget calculations. We would like to thank Rafael Blättler, Eytan Gur, Kate Gassner, Ruth Stierli, Beat Müller, Stefan Koetzsch, Mark Rollog, and Torsten Diem for their assistance with field experiments or laboratory analyses. We are grateful to Mario Schirmer (Eawag) and Joseph Zeyer (ETH Zurich) for supporting this work. This work is part of the project REstored CORridor Dynamics (RECORD) and supported by the Competence Center Environment and Sustainability (CCES) of the ETH Domain.

Edited by: C. P. Slomp

\section{References}

Abbaspour, K. C., Yang, J., Maximov, I., Siber, R., Bogner, K., Mieleitner, J., Zobrist, J., and Srinivasan, R.: Modelling hydrology and water quality in the pre-alpine/alpine Thur watershed using SWAT, J. Hydrol., 333, 413-430, 2007.

Aronsson, P. and Perttu, K.: Willow vegetation filters for wastewater treatment and soil remediation combined with biomass production, Forest Chron, 77, 293-299, 2001.

Baker, M. A. and Vervier, P.: Hydrological variability, organic matter supply and denitrification in the Garonne River ecosystem, Freshwater Biol., 49, 181-190, 2004.

Baker, M., Dahm, C., and Valett, H.: Acetate retention and metabolism in the hyporheic zone of a mountain stream, Limnol. Oceanogr., 44, 1530-1539, 1999.

Benner, R. and Strom, M.: A critical-evaluation of the analytical blank associated with DOC measurements by high-temperature catalytic-oxidation, Mar. Chem., 41, 153-160, 1993.

Binderheim-Bankay, E., Jakob, A., and Liechti, P.: NADUF Messresultate 1977-1998, Federal Office for the Environment (FOEN), Bern, 241, 2000.

Boulton, A. J.: Hyporheic rehabilitation in rivers: restoring vertical connectivity, Freshwater Biol., 52, 632-650, doi:10.1111/j.13652427.2006.01710.x, 2007.

Brankatschk, R., Töwe, S., Kleineidam, K., Schloter, M., and Zeyer, $\mathrm{J}$.: Abundances and potential activities of nitrogen cycling microbial communities along a chronosequence of a glacier forefield, ISME J., 5, 1025-1037, doi:10.1038/ismej.2010.184, 2010.

Brankatschk, R., Bodenhausen, N., Zeyer, J., and Bürgmann, H.: Efficiency of real-time qPCR depends on the template: a simple absolute quantification method correcting for qPCR efficiency variations in microbial community samples, Appl. Environ. Microb., doi:10.1128/AEM.07878-11, 2012.

Burt, T. and Pinay, G.: Linking hydrology and biogeochemistry in complex landscapes, Prog. Phys. Geog., 29, 297-316, 2005.

Casciotti, K. L., Sigman, D. M., Hastings, M. G., Bohlke, J. K., and Hilkert, A.: Measurement of the oxygen isotopic composition of nitrate in seawater and freshwater using the denitrifier method, Anal. Chem., 74, 4905-4912, doi:10.1021/Ac020113w, 2002.

Cey, E., Rudolph, D., Aravena, R., and Parkin, G.: Role of the riparian zone in controlling the distribution and fate of agricultural nitrogen near a small stream in southern Ontario, J. Contam. Hydrol., 37, 45-67, 1999. 
Clement, J. C., Holmes, R. M., Peterson, B. J., and Pinay, G.: Isotopic investigation of denitrification in a riparian ecosystem in western France, J. Appl. Ecol., 40, 1035-1048, 2003.

Clinton, S. M., Edwards, R. T., and Naiman, R. J.: Forest-river interactions: Influence on hyporheic dissolved organic carbon concentrations in a floodplain terrace, J. Am. Water Resour. As., 38, 619-631, 2002.

Clinton, S. M., Edwards, R. T., and Findlay, S. E. G.: Exoenzyme activities as indicators of dissolved organic matter composition in the hyporheic zone of a floodplain river, Freshwater Biol., 55, 1603-1615, doi:10.1111/j.1365-2427.2009.02383.x, 2010.

Codispoti, L., Brandes, J., Christensen, J., Devol, A., Naqvi, S., Paerl, H., and Yoshinari, T.: The oceanic fixed nitrogen and nitrous oxide budgets: Moving targets as we enter the anthropocene?, Sci. Mar., 65, 85-105, 2001.

Craig, L., Bahr, J., and Roden, E.: Localized zones of denitrification in a floodplain aquifer in southern Wisconsin, USA, Hydrogeol. J., 18, 1867-1879, 2010.

de Neergaard, A., Porter, J. R., and Gorissen, A.: Distribution of assimilated carbon in plants and rhizosphere soil of basket willow (Salix viminalis L.), Plant Soil, 245, 307-314, 2002.

DEV: Deutsches Einheitsverfahren zur Wasseruntersuchung (DEW), Wiley-VCH Verlag GmbH, Weimheim, Germany, 2004.

Dhondt, K., Boeckx, P., Van Cleemput, O., and Hofman, G.: Quantifying nitrate retention processes in a riparian buffer zone using the natural abundance of ${ }^{15} \mathrm{~N}$ in $\mathrm{NO}_{3}^{-}$, Rapid Commun. Mass Sp., 17, 2597-2604, doi:10.1002/Rcm.1226, 2003.

Dhondt, K., Boeckx, P., Verhoest, N. E. C., Hofman, G., and Van Cleemput, O.: Assessment of temporal and spatial variation of nitrate removal in riparian zones, Environ. Monit. Assess., 116, 197-215, doi:10.1007/s10661-006-7403-1, 2006.

Diem, S., Renard, P., and Schirmer, M.: Impact of river water level uncertainty on modeled groundwater residence times, in preparation, 2012.

Dosskey, M. G., Vidon, P., Gurwick, N. P., Allan, C. J., Duval, T. P., and Lowrance, R.: The role of riparian vegetation in protecting and improving chemical water quality in streams, J. Am. Water Resour. As., 46, 261-277, doi:10.1111/j.17521688.2010.00419.x, 2010.

Edwards, R.: The hyporheic zone, in: River ecology and management: Lessons from the pacific coastal ecoregion, edited by: Naiman, R. J. and Bilby, R. E., New York, Springer-Verlag, 399429, 1998.

Elowson, S.: Willow as a vegetation filter for cleaning of polluted drainage water from agricultural land, Biomass Bioenerg., 16, 281-290, 1999.

Findlay, S. and Sinsabaugh, R. L.: Aquatic Ecosystems: Interactivity of Dissolved Organic Matter, Academic Press, San Diego, 2003.

Findlay, S. E. G., Mulholland, P. J., Hamilton, S. K., Tank, J. L., Bernot, M. J., Burgin, A. J., Crenshaw, C. L., Dodds, W. K., Grimm, N. B., McDowell, W. H., Potter, J. D., and Sobota, D. J.: Cross-stream comparison of substrate-specific denitrification potential, Biogeochemistry, 104, 381-392, doi:10.1007/s10533010-9512-8, 2011.

Fisher, S. G., and Weiter, J. R.: Flowpaths as integrators of heterogeneity in streams and landscapes, in: Ecosystem Function in Heterogeneous Landscapes, edited by: Lovett, G. M., Turner, M. G., Jones, C. G., and Weathers, K. C., Springer science, 311-328,
2005.

Fischer, H., Sachse, A., Steinberg, C. E. W., and Pusch, M.: Differential retention and utilization of dissolved organic carbon by bacteria in river sediments, Limnol. Oceanogr., 47, 1702-1711, 2002.

Gift, D. M., Groffman, P. M., Kaushal, S. S., and Mayer, P. M.: Denitrification potential, root biomass, and organic matter in degraded and restored urban riparian zones, Restor. Ecol., 18, 113120, doi:10.1111/j.1526-100X.2008.00438.x, 2010.

Grasshoff, K., Kremling, K., and Ehrhardt, M.: Methods of seawater analysis. Third, completely revised and extended edition, WileyVCH, Weinheim, 77, 160, 1999.

Gruber, N. and Galloway, J.: An Earth-system perspective of the global nitrogen cycle, Nature, 451, 293-296, 2008.

Hallin, S., Jones, C., Schloter, M., and Philippot, L.: Relationship between $\mathrm{N}$-cycling communities and ecosystem functioning in a 50-year-old fertilization experiment, ISME J., 3, 597-605, 2009.

Hefting, M., Clement, J., Dowrick, D., Cosandey, A., Bernal, S., Cimpian, C., Tatur, A., Burt, T., and Pinay, G.: Water table elevation controls on soil nitrogen cycling in riparian wetlands along a European climatic gradient, Biogeochemistry, 67, 113134, 2004.

Hinkle, S., Duff, J., Triska, F., Laenen, A., Gates, E., Bencala, K., Wentz, D., and Silva, S.: Linking hyporheic flow and nitrogen cycling near the Willamette River - a large river in Oregon, USA, J. Hydrol., 244, 157-180, 2001.

Huber, B., Luster, J., Bernasconi, S. M., Shrestha, J., and Graf Pannatier, E.: Nitrate leaching from short-hydroperiod floodplain soils, Biogeosciences Discuss., 9, 5659-5694, doi:10.5194/bgd9-5659-2012, 2012.

Jansson, P. E. and Moon, D. S.: A coupled model of water, heat and mass transfer using object orientation to improve flexibility and functionality, Environ. Modell. Softw., 16, 37-46, 2001.

Kendall, C. and Caldwell, E.: Fundamentals of isotope geochemistry, in: Isotope tracers in catchment hydrology, edited by: Kendall, C. and McDonnell, J. J., Elsevier, 51-86, 1998.

Kim, D.-G., Isenhart, T. M., Parkin, T. B., Schultz, R. C., and Loynachan, T. E.: Nitrate and dissolved nitrous oxide in groundwater within cropped fields and riparian buffers, Biogeosciences Discuss., 6, 651-685, doi:10.5194/bgd-6-651-2009, 2009.

Kuzovkina, Y. A. and Volk, T. A.: The characterization of willow (Salix L.) varieties for use in ecological engineering applications: Co-ordination of structure, function and autecology, Ecol. Eng., 35, 1178-1189, 2009.

Lalke-Porczyk, E., Brzezinska, M., and Donderski, W.: Influence of the root system of the common osier (Salix viminalis L.) on abundance of heterotrophic bacteria in the willow sewage treatment system, Curr. Microbiol., 58, 571-577, 2009.

Lehmann, M. F., Reichert, P., Bernasconi, S. M., Barbieri, A., and McKenzie, J.: Modelling nitrogen and oxygen isotope fractionation during denitrification in a lacustrine redox-transition zone, Geochim. Cosmochim. Ac., 67, 2529-2542, 2003.

Lund, L., Horne, A., and Williams, A.: Estimating denitrification in a large constructed wetland using stable nitrogen isotope ratios, Ecol. Eng., 14, 67-76, 1999.

Malard, F., Tockner, K., Dole-Olivier, M. J., and Ward, J. V.: A landscape perspective of surface-subsurface hydrological exchanges in river corridors, Freshwater Biol., 47, 621-640, 2002. 
Mariotti, A., Germon, J., Hubert, P., Kaiser, P., Letolle, R., Tardieux, A., and Tardieux, P.: Experimental determination of nitrogen kinetic isotope fractionation: some principles; illustration for the denitrification and nitrification processes, Plant Soil, 62, 413430, 1981.

Matsui, K., Ishii, N., Honjo, M., and Kawabata, Z.: Use of the SYBR Green I fluorescent dye and a centrifugal filter device for rapid determination of dissolved DNA concentration in fresh water, Aquat. Microb. Ecol., 36, 99-105, 2004.

Mayer, P. M., Reynolds, S. K., Marshall, D., McCutchen, M. D., and Canfield, T. J.: Meta-analysis of nitrogen removal in riparian buffers, J. Environ. Qual., 36, 1172-1180, doi:10.2134/Jeq2006.0462, 2007.

Mayer, P. M., Groffman, P. M., Striz, E. A., and Kaushal, S. S.: Nitrogen Dynamics at the Groundwater-Surface Water Interface of a Degraded Urban Stream, J. Environ. Qual., 39, 810-823, 2010.

McClain, M. E., Boyer, E. W., Dent, C. L., Gergel, S. E., Grimm, N. B., Groffman, P. M., Hart, S. C., Harvey, J. W., Johnston, C. A., Mayorga, E., McDowell, W. H., and Pinay, G.: Biogeochemical hot spots and hot moments at the interface of terrestrial and aquatic ecosystems, Ecosystems, 6, 301-312, 2003.

Mengis, M., Gachter, R., and Wehrli, B.: Nitrous oxide emissions to the atmosphere from an artificially oxygenated lake, Limnol. Oceanogr., 41, 548-553, 1996.

Mengis, M., Schiff, S. L., Harris, M., English, M. C., Aravena, R., Elgood, R. J., and MacLean, A.: Multiple geochemical and isotopic approaches for assessing ground water $\mathrm{NO}_{3}^{-}$elimination in a riparian zone, Ground Water, 37, 448-457, 1999.

Naqvi, S., Jayakumar, D., Narvekar, P., Naik, H., Sarma, V., D’ Souza, W., Joseph, S., and George, M.: Increased marine production of $\mathrm{N}_{2} \mathrm{O}$ due to intensifying anoxia on the Indian continental shelf, Nature, 408, 346-349, 2000.

Pasquale, N., Perona, P., Schneider, P., Shrestha, J., Wombacher, A., and Burlando, P.: Modern comprehensive approach to monitor the morphodynamic evolution of a restored river corridor, Hydrol. Earth Syst. Sci., 15, 1197-1212, doi:10.5194/hess-151197-2011, 2011.

Pasquale, N., Perona, P., Francis, R., and Burlando, P.: Effects of streamflow variability on the vertical root density distribution of willow cutting experiments, Ecol. Eng., 40, 167-172, 2012.

Peter, S., Koetzsch, S., Traber, J., Bernasconi, S. M., Wehrli, B., and Durisch-Kaiser, E.: Intensified organic carbon dynamics in the groundwater of a restored riparian zone, Freshwater Biol., 54, 1603-1616, doi:10.1111/j.1365-2427.2012.02821.x, 2012.

Philippot, L., Cuhel, J., Saby, N., Chèneby, D., Chronakova, A., Bru, D., Arrouays, D., Martin-Laurent, F., and Simek, M.: Mapping field-scale spatial patterns of size and activity of the denitrifier community, Environ. Microbiol., 11, 1518-1526, 2009.
Powlson, D. S., Addisott, T. M., Benjamin, N., Cassman, K. G., de Kok, T. M., van Grinsven, H., L'hirondel, J. L., Avery, A. A., and van Kessel, C.: When does nitrate become a risk for humans?, J. Environ. Qual., 37, 291-295, doi:10.2134/Jeq2007.0177, 2008.

Rivett, M. O., Buss, S. R., Morgan, P., Smith, J. W. N., and Bemment, C. D.: Nitrate attenuation in groundwater: A review of biogeochemical controlling processes, Water Res., 42, 4215-4232, doi:10.1016/j.watres.2008.07.020, 2008.

Ruijter, J. M., Ramakers, C., Hoogaars, W. M. H., Karlen, Y., Bakker, O., van den Hoff, M. J. B., and Moorman, A. F. M.: Amplification efficiency: linking baseline and bias in the analysis of quantitative PCR data, Nucleic Acids Res., 37, 1-12, doi:10.1093/nar/gkp045, 2009.

Schade, J. D., Fisher, S. G., Grimm, N. B., and Seddon, J. A.: The influence of a riparian shrub on nitrogen cycling in a Sonoran Desert stream, Ecology, 82, 3363-3376, 2001.

Schneider, P., Vogt, T., Schirmer, M., Doetsch, J., Linde, N., Pasquale, N., Perona, P., and Cirpka, O. A.: Towards improved instrumentation for assessing river-groundwater interactions in a restored river corridor, Hydrol. Earth Syst. Sci., 15, 2531-2549, doi:10.5194/hess-15-2531-2011, 2011.

Seitzinger, S., Harrison, J. A., Bohlke, J. K., Bouwman, A. F., Lowrance, R., Peterson, B., Tobias, C., and Van Drecht, G.: Denitrification across landscapes and waterscapes: A synthesis, Ecol. Appl., 16, 2064-2090, 2006.

Sigman, D. M., Casciotti, K. L., Andreani, M., Barford, C., Galanter, M., and Bohlke, J. K.: A bacterial method for the nitrogen isotopic analysis of nitrate in seawater and freshwater, Anal. Chem., 73, 4145-4153, 2001.

Sobczak, W. V. and Findlay, S.: Variation in bioavailability of dissolved organic carbon among stream hyporheic flowpaths, Ecology, 83, 3194-3209, 2002.

Thorp, J. H., Thoms, M. C., and Delong, M. D.: The riverine ecosystem synthesis: Biocomplexity in river networks across space and time, River Res. Appl., 22, 123-147, 2006.

Tockner, K. and Stanford, J. A.: Riverine flood plains: present state and future trends, Environ. Conserv., 29, 308-330, 2002.

Verhoeven, J. T. A., Arheimer, B., Yin, C. Q., and Hefting, M. M.: Regional and global concerns over wetlands and water quality, Trends Ecol. Evol., 21, 96-103, doi:10.1016/j.tree.2005.11.015, 2006.

Vogt, T., Hoehn, E., Schneider, P., Freund, A., Schirmer, M., and Cirpka, O.: Fluctuations of electrical conductivity as a natural tracer for bank filtration in a losing stream, Adv. Water Resour., 33, 1296-1308, doi:10.1016/j.advwatres.2010.02.007, 2010.

Vogt, T., Schirmer, M., and Cirpka, O. A.: Investigating riparian groundwater flow close to a losing river using diurnal temperature oscillations at high vertical resolution, Hydrol. Earth Syst. Sci., 16, 473-487, doi:10.5194/hess-16-473-2012, 2012.

Weiss, R. F., and Price, B. A.: Nitrous-oxide solubility in water and seawater, Mar. Chem., 8, 347-359, 1980. 